\title{
Influence of synthesis conditions on molecular weight as well as mechanical and thermal properties of poly(hexamethylene 2,5-furanate)
}

\author{
Sandra Paszkiewicz ${ }^{1)}$, *) (ORCID: 0000-0001-7487-9220), Izabela Irska1) (0000-0002-5521-1847), \\ Konrad Walkowiak ${ }^{1)}$ (0000-0001-8629-7367), Agata Zubkiewicz ${ }^{1)}$ (0000-0001-6759-0250)
}

DOI: dx.doi.org/10.14314/polimery.2021.10.3

\begin{abstract}
Poly(hexamethylene 2,5-furanate) (PHF) was obtained by melt polycondensation. The process was carried out at temperatures of 230,235 and $240^{\circ} \mathrm{C}$. It has been shown that the selection of the optimal parameters of the synthesis process leads to the obtaining of biomaterials of high molecular weight, and thus better mechanical and thermal properties. The relationship between the molecular weight and the mobility of polymer chains, and consequently the temperature of phase changes and mechanical properties, was determined.
\end{abstract}

Keywords: melt polycondensation, poly(hexamethylene 2,5-furanodicarboxylate), molecular weight, chain mobility, mechanical properties, thermal properties.

\section{Wpływ warunków syntezy na masę cząsteczkową oraz właściwości mechaniczne i termiczne poli(2,5-furanianu heksametylenowego)}

\begin{abstract}
Streszczenie: Poli(2,5-furanian heksametylenowy) (PHF) otrzymano metodą polikondensacji w stanie stopionym. Proces prowadzono w temperaturze 230,235 i $240^{\circ} \mathrm{C}$. Wykazano, że dobór optymalnych parametrów procesu syntezy prowadzi do otrzymania biomateriałów o dużej masie cząsteczkowej, a tym samym lepszych właściwościach mechanicznych i termicznych. Określono zależność między masą cząsteczkową a ruchliwością łańcuchów polimerowych, a w konsekwencji temperaturą przemian fazowych i właściwościami mechanicznymi.
\end{abstract}

Słowa kluczowe: polikondesacja w stanie stopionym, poli(2,5-furanian heksametylenowy), masa cząsteczkowa, ruchliwość łańcuchów polimerowych, właściwości mechaniczne, właściwości termiczne.

The beginnings of the thermoplastic polyesters industrial production date back to the 1950s, and these materials were used then only for the production of fibers and electrical insulating films [1, 2]. In the 1960s, thermoplastic polyesters were first introduced to the market as engineering plastics: Arnite (Akzo), Rynite (DuPont), and Celanex (Celanese Corporation) [2]. Currently, two basic types of the discussed materials are produced on an industrial scale: poly (ethylene terephthalate) (PET) and poly (butylene terephthalate) (PBT), however, polyesters based on other homologues, 1,3-propylene glycol (PTT) and 1,6-hexylene glycol (PHT), despite equally good, and sometimes even better performance properties, did not receive such great interest from the industry. All of above mentioned materials differ in both physicochemical and mechanical properties, above all in temperature and rate of crystallization, which results

1) West Pomeranian University of Technology, al. Piastów 17, 70-310 Szczecin, Poland

*) Author for correspondence: spaszkiewicz@zut.edu.pl in differences in their processing. Especially PET, due to its combination of unique physical, mechanical and barrier properties, is widely used in the packaging industry. However, the constantly growing amount of packaging waste, especially bottles, and the decreasing amount of non-renewable resources (such as crude oil and natural gas) have contributed to the interest in bio-based materials (based on renewable raw materials). Within this context, 2,5-furan dicarboxylic acid (FDCA), or its ester derivative (dimethyl 2,5-furandicarboxylate (DMFDC), are monomers obtained from sugars and are the first candidates to replace petrol-originated terephthalic acid $[3,4]$. The polyesters, obtained from FDCA, especially poly(ethylene 2,5-furan dicarboxylate) (PEF) are successfully treated as bio-based alternatives and are produced and applied in a vast amount of commercial applications [5-7]. PEF is already widely studied [8], but the growing interest is now focused on its blends or copolymers with other polymers $[9,10]$, or FDCA-based polyesters with other glycols [11-13]. Our group is mainly interested in the possibilities of synthesis and properties of polyes- 
ters and copolyesters based on FDCA (or DMFDC) and 1,3-propanediol or 1,6-hexanediol [14-16]. Of course, several papers on PHF have already been published [17-24], including 2 of our latest works [15, 16]. However, none of these publications systematically presents how the synthesis conditions of PHF affect its physicochemical properties and, consequently, its utilitarian performance. Most of the currently tested thermoplastic polyesters based on renewable raw materials, such as FDCA or FDADM and 1,6-hexanediol, are obtained on a laboratory scale, and in most cases, only the basic properties of these materials are analyzed, while the analysis of mechanical properties is often performed on the pressed samples. In our case, three PHFs were obtained by the melt polycondensation, which has been used for many years to obtain polyesters and thermoplastic elastomers based on petrochemical raw chemical, such as PET, PBT, etc. [2], and recently its effectiveness for obtaining bio-based materials has been confirmed [14-16, 25-27]. Moreover, herein the test specimens are obtained by injection molding. This study aims to compare the properties of 3 polyesters based on FDADM and 1,6-hexanediol (both raw materials of plant origin) synthesized by the melt polycondensation method at different temperatures of the polycondensation process (second stage of synthesis).

\section{EXPERIMENTAL PART}

\section{Preparation of poly(hexamethylene 2,5-furanodicarboxylate)}

Three PHFs were synthesized from renewable raw materials: dimethyl 2,5-furanodicarboxylate (DMFDC, 99\%, Henan Coreychem Co., Ltd., China) and 1,6-hexylene glycol (HDO, Rennovia Inc., Santa Clara, CA, USA). The details of the synthesis procedure can be found in our previously published paper [16], but in brief: the process consisted of two stages, transesterification of DMFDC by $\mathrm{HDO}$ in the presence of the first portion of catalyst (tetrabuthyl orthotitanate, $\mathrm{Ti}(\mathrm{OBu}) 4$, (Fluka)), and the second step of polycondensation, in the presence of the second portion of catalyst (also $\left.\mathrm{Ti}(\mathrm{OBu})_{4}\right)$ and thermal stabilizer, Irganox 1010 (Ciba - Geigy, Switzerland). The reaction was carried out in the 11 high-pressure reactor (Autoclave Engineers Pennsylvania, USA). The transesterification reaction was carried out under nitrogen constant flow at the temperature range of $160-180^{\circ} \mathrm{C}$ for about two hours, wherein the first by-product, methanol, was distilled and collected. When this step was completed, the temperature was gradually increased up to $210^{\circ} \mathrm{C}$ and the thermal stabilizer and the second portion of the catalyst were added. The reaction temperature of the second step was different for three PHFs: i) $230^{\circ} \mathrm{C}$ (PHF_1), ii) $235^{\circ} \mathrm{C}$ (following [20], PHF_2)), and iii) $240^{\circ} \mathrm{C}$ (PHF_3, the same as in [16]), under vacuum. The polycondensation process was found to be finished when the reaction mixture reached the appropriate value of melt viscosity (referring to a high molecu- lar mass of the polymer material). Finally, the material was extruded from the reactor into the water bath using compressed nitrogen.

All of the obtained materials were pelletized and injection molded using Boy 15 (Dr. BOY GmbH\&Co., Germany) to obtain dumbbell shape samples, type A3, for tensile measurements. Samples before the processing were dried for $24 \mathrm{~h}$ under a vacuum at the temperature of $50^{\circ} \mathrm{C}$, while the injection parameters can be found in [16]. Besides, the chemical structure of PHF_3 was confirmed by both ${ }^{1} \mathrm{H}$ NMR and FTIR analyses, and its crystallization behavior was confirmed by both DSC and XRD in [16], thus confirming the effectiveness of the polycondensation method to obtain bio-based polyesters, and the stoichiometric calculations on the structure of the synthesized materials.

\section{Characterization methods}

The intrinsic viscosity [IV] was determined at $30^{\circ} \mathrm{C}$ in the mixture of phenol/1,1,2,2-tetrachloroethane (60/40 by weight). The concentration of the polymer solution was $0.5 \mathrm{~g} / \mathrm{dl}$. The measurement was carried using a capillary Ubbelohde viscometer (type Ic, $\mathrm{K}=0.03294$ ). The number $\left(\bar{M}_{n}\right)$ and weight average molecular masses $\left(\bar{M}_{w}\right)$, as well as polydispersity index $\left(M_{w} / M_{n}\right)$, were evaluated using Size Exclusion Chromatography (SEC) in 1,1,1,3,3,3-hexafluoroisopropanol (HFIP) at $40^{\circ} \mathrm{C}$ following the procedure published in [1]. Differential scanning calorimetry (DSC) measurements were performed on a DSC 204 F1 Phoenix (Netzsch, Selb, Germany), under nitrogen atmosphere in the heating-cooling-heating cycle, with the heating/cooling rate of $10^{\circ} \mathrm{C} / \mathrm{min}$, from -75 to $210^{\circ} \mathrm{C}$. The characteristic phase transition temperatures (glass transition and melting) were taken from the second heating run. Besides, the softening temperatures $\left(T_{B}\right)$ were determined at Boetius apparatus (HMK 71/3407, Franz Küstner Nachf. KG, Dresden, Germany), where the changes in polymers structure along with an increase in temperature, and the moment (temperature range), in which the crystalline phase completely disappears can be observed. The static mechanical properties were measured using Autograph AG-X plus universal testing machine (Shimadzu, Kyoto, Japan) at a constant crosshead speed of $5 \mathrm{~mm} / \mathrm{min}$, according to PN-EN ISO 527 standard.

\section{RESULTS AND DISCUSSION}

The highly important issue allowing to understand the improvement in mechanical properties and influence on thermal behavior in polymer materials is the relation between molecular masses and the polymers' chains mobility.

In Table 1 general characteristics of synthesized PHFs at different polycondensation temperatures $\left(T_{p}\right)$ were summarized, by means of intrinsic viscosity, numberand weight-average molecular masses $\left(M_{n}\right.$ and $M_{w^{\prime}}$ 
T a b l e 1. General characteristics of PHFs

\begin{tabular}{c|c|c|c|c|c|c|c|c|c|c|c}
\hline Sample & $\begin{array}{c}T_{P} \\
{ }^{\circ} \mathrm{C}\end{array}$ & $\begin{array}{c}\mathrm{IV} \\
\mathrm{dl} / \mathrm{g}\end{array}$ & $\begin{array}{c}M_{n} \\
\mathrm{~g} / \mathrm{mol}\end{array}$ & $\begin{array}{c}M_{w} \\
\mathrm{~g} / \mathrm{mol}\end{array}$ & $\mathrm{PDI}$ & $\begin{array}{c}T_{B} \\
{ }^{\circ} \mathrm{C}\end{array}$ & $\begin{array}{c}E \\
\mathrm{MPa}\end{array}$ & $\begin{array}{c}\sigma_{y} \\
\mathrm{MPa}\end{array}$ & $\begin{array}{c}\varepsilon_{y} \\
\%\end{array}$ & $\begin{array}{c}\sigma_{b} \\
\mathrm{MPa}\end{array}$ & $\begin{array}{c}\varepsilon_{b} \\
\%\end{array}$ \\
\hline PHF_1 & 230 & 0.708 & 31,280 & 65,160 & 2.08 & $144-152$ & $642.2 \pm 45.7$ & $25.6 \pm 0.6$ & $8.0 \pm 0.4$ & $47.0 \pm 0.9$ & $292.9 \pm 13.6$ \\
PHF_2 & 235 & 0.825 & 33,240 & 68,320 & 2.05 & $146-154$ & $731.8 \pm 37.7$ & $27.3 \pm 0.4$ & $9.8 \pm 0.4$ & $54.8 \pm 1.8$ & $327.0 \pm 17.3$ \\
PHF_3 & 240 & 0.532 & 19,200 & 54,100 & 2.82 & $143-152$ & $423.8 \pm 84.6$ & $25.9 \pm 0.8$ & $7.2 \pm 0.6$ & $18.7 \pm 1.4$ & $193.7 \pm 12.7$ \\
\hline
\end{tabular}

$T_{P}$ - temperature of the second step of synthesis process

IV - intrinsic viscosity

$M_{n}$ - number-average molecular mass

$M_{w}$ - weight-average molecular mass

PDI - polydispersity index

$T_{B}$ - Boetius softening temperature

$E$ - Young's Modulus (calculated from linear slope of the stress-strain curve, from $0.05 \%$ to $0.25 \%$ strain)

$\sigma_{y^{\prime}} \varepsilon_{\mathrm{y}}$ - tensile strength and elongation at yield

$\sigma_{\mathrm{b}^{\prime}} \varepsilon_{\mathrm{b}}-$ tensile strength and elongation at break, respectively

respectively), along with Boetius softening temperature and tensile characteristics.

In Fig. 1 DSC traces recorded during cooling and second heating were compiled and the characteristic phase transitions temperatures, i.e. glass transition temperature (and corresponding heat capacity), melting, and crystallization temperatures were marked (Table 2).

Because furan-based polyesters constitute a relatively new subject of research, especially those based on glycols with three or more methylene groups, as 1,3-propanediol, or in this case 1,6-hexanediol, there are few publications on their synthesis, and in particular, preparation methods by means of polycondensation in the molten state, which, due to the applicability of the industry, is of particular importance. The authors, by trial and error method, and

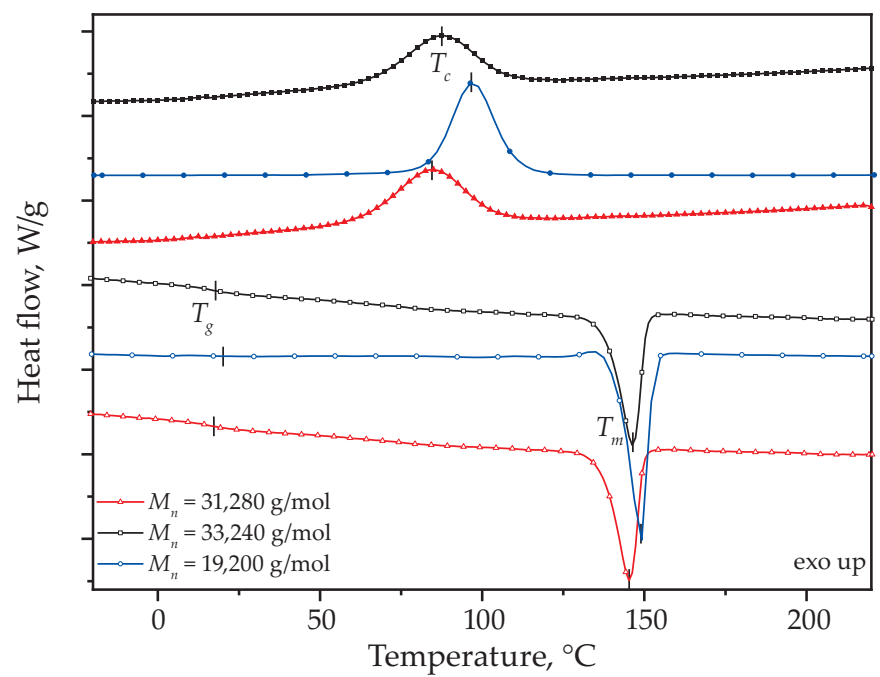

Fig. 1. DSC curves recorded during cooling and second heating of PHFs based on experience in the synthesis of polyesters and literature data, decided to carry out the syntheses of PHF at 230, 235, and $240{ }^{\circ} \mathrm{C}$, and labeled them as PHF_1, PHF_2, and PHF_3, respectively. It was noted, that the highest value of IV and molecular masses were obtained when the final step of synthesis was $235^{\circ} \mathrm{C}$. On the other hand, at a temperature $5^{\circ} \mathrm{C}$ higher $\left(240^{\circ} \mathrm{C}\right)$, the lowest values of molecular masses were obtained. It is clearly noted, that at lower polycondensation temperatures $\left(230\right.$ and $\left.235^{\circ} \mathrm{C}\right)$, higher values of IV, $M_{n}$ and $M_{w}$ were received. For example, the difference in the IV values for PHF_2 and PHF_3 was over $55 \%$, while in the values on $M_{n}$ over $70 \%$. It is also worth noting the values of PDI, which provides information on the heterogeneity of a sample and polymer chains length distribution. In this case, PHF_1 and PHF_2 exhibited similar values of PDI (ca. 2), while PHF_3 exhibited a significantly higher value of 2.82 , which clearly confirms that the synthesis process should be carried out in lower values of $T_{p}$. Besides, the effect of the molecular mass value of the synthesized polymers on the phase transition temperatures was observed (Fig. 1). For all PHFs changes in the values of $T_{g^{\prime}}$ and the corresponding $\Delta C_{p^{\prime}}$ resulting from the average length of polymer chains, their distribution, and mobility were observed. The polymer with the highest $M_{n^{\prime}} M_{w}$ (PHF_2) underwent the glass transition at higher temperatures. Similar observations were made on the values of melting and crystallization temperatures. While the differences are not so significant in the case of melting (second heating scan), the effect of chain length on crystallization behavior was clearly visible in the cooling traces. Differences of over $15^{\circ} \mathrm{C}$ were observed between the materials most differing in the values of molecular masses, i.e. PHF_2

T a b l e 2. DSC data of PHFs synthesized at different conditions

\begin{tabular}{c|c|c|c|c|c|c}
\hline Sample & $M_{n^{\prime}} \mathrm{g} / \mathrm{mol}$ & $T_{g^{\prime}}{ }^{\circ} \mathrm{C}$ & $\Delta C_{p^{\prime}} \mathrm{J} / \mathrm{g}$ & $T_{c^{\prime}}{ }^{\circ} \mathrm{C}$ & $T_{m^{\prime}}{ }^{\circ} \mathrm{C}$ & $X_{c^{\prime}} \%$ \\
\hline PHF_1 & 31,280 & 16.6 & 0.26 & 84 & 144 & 32.5 \\
PHF_2 & 33,240 & 17.1 & 0.22 & 89 & 146 & 37.1 \\
PHF_3 & 19,200 & 17.6 & 0.21 & 96 & 149 & 38.3 \\
\hline
\end{tabular}


and PHF_3. Besides, PHF_2 exhibited also the highest value of the crystallinity degree (38.3\%). The growth of nuclei requires sufficient mobility of polymer chains, which is noticeably evident in the following observations. Besides, as the free volume continues to increase along with increasing temperature, the glass transition occurs where large chain segments start moving, whereby the transition is dependent on the degree of polymerization or the critical molecular weight $[28,29]$. Additionally, Hao et al. [30] found that the higher the molecular mass, the stronger the crystallization ability, which is in the agreement with the observations made herein. Moreover, the values of heat capacities, corresponding to $T_{g^{\prime}}$ are in the agreement with the estimations of the crystallinity degree, since $T_{g}$ occurs in either amorphous materials or amorphous region in the materials, so the corresponding heat capacities exhibited lower values for materials with higher $M_{w^{\prime}}$ and thus $T_{g}$ and $X_{c}$ (PHF_2). Besides, the observations on the Boetius softening temperature (Table 1) confirm the above findings on the phase transition temperatures determined by the DSC method, i.e. the values of $T_{B}$ occur in order: PHF_2 $>$ PHF_1 $>$ PHF_3.

It is well established that the tensile properties such as tensile strength and elongation at break increase with the increase of molecular weight or narrowing molecularweight distribution. This effect reaches a limit at a certain and relatively high $M_{w}$, where there is no longer any significant change in mechanical properties with increasing $M_{w}$ [29-32]. The stress-strain curves of the synthesized PHFs are collected in Figure 2, and the corresponding results are summarized in Table 1.

At the very first glance, it can be noted that synthesized PHFs are exhibiting stress-strain behavior characteristic for semi-crystalline polymers with a clear elastic, yielding, plastic strain hardening, and failure sections, with the exception of PHF_3 sample. The latter material exhibiting the most disordered structure

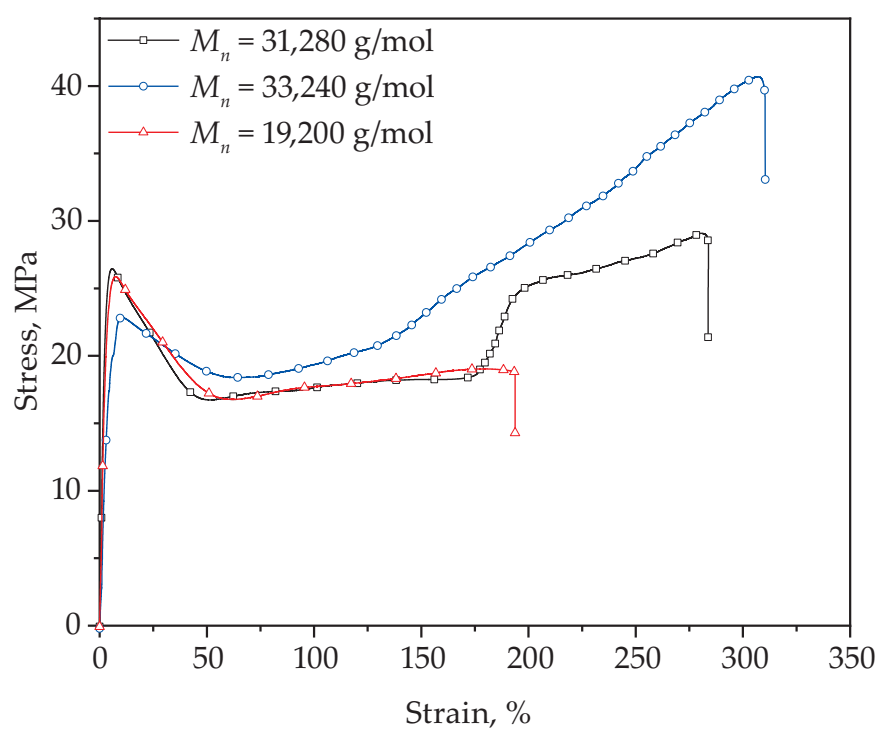

Fig. 2. Representative stress-strain curves of PHFs (as inferred from GPC and calorimetric studies) is not able to crystallize under mechanical loading and breaks without evident strain hardening at a tensile stress of ca. $19 \mathrm{MPa}$ and elongation of about $194 \%$. As expected, the mechanical performance appeared to be correlated to PHFs molecular mass and the synthesis conditions as a consequence. The positive relationship between the PHF molecular mass and the mechanical performance is reflected in the values of Young's modulus, tensile strength, and elongation at break, which increase in the order of PHF_3 $<$ PHF_1 $<$ PHF_2. By increasing Mn from $19200 \mathrm{~g} / \mathrm{mol}$ to $33240 \mathrm{~g} / \mathrm{mol}$, the tensile strength at break increased from $18.7 \pm 1.4 \mathrm{MPa}$ to $54.8 \pm 1.8 \mathrm{MPa}$, the strain at break increased from $193.7 \pm 12.7 \%$ to $327.0 \pm 17.3 \%$, whilst the Young's modulus increased from $423.8 \pm 84.6 \mathrm{MPa}$ to 642.2 $\pm 45.7 \mathrm{MPa}$. The observed trend can be reasonably explained by the fact that PHF's with the higher molecular mass, thus with longer and less flexible polymer chains, are more prone to macromolecular orientation and crystallization under tensile stress. It is also worth mentioning that the synthesized PHF_2 is exhibiting superior mechanical performance (tensile strength and elongation a break of 54.8 and 327.0, respectively), markedly higher than that reported for PHF by Zhang J. et al. [17] and more recently by Guidotti G. et al. [21].

\section{CONCLUSIONS}

Three poly(hexamethylene 2,5-furanoates) were obtained employing polycondensation in the molten state process based on renewable raw monomers (DMFDC, Henan Coreychem Co., and HDO, Rennovia Inc.). It was found that determining the temperature of the polycondensation process is of key practical importance. The most optimal polycondensation temperature to obtain PHF with the highest molecular mass and thus the finest mechanical and thermal properties, was $235^{\circ} \mathrm{C}$. The authors related the discussion on values of the molecular masses with the molecular mobility and the ability of the material to crystallize. It was found that along with the chain length increase, the mobility of the molecular chains is restricted. Besides, it was proved, that PHFs with the higher molecular mass, thus with longer and less flexible polymer chains, are more prone to macromolecular orientation and crystallization under tensile stress.

\section{ACKNOWLEDGEMENTS}

The studies were financed by the National Science Centre within project SONATA no 2018/31/D/ST8/00792.

\section{REFERENCES}

[1] Fakirov S: "Handbook of Thermoplastic Polyesters: Homopolymers, Copolymers, Blends, and Composites", WILEY -VCH Verlag GmbH: Weinheim, 2002, p 1-57. 
[2] Long T.E.: "Modern Polyesters: Chemistry and Technology of Polyesters and Copolyesters", John Wiley \& Sons, Ltd: New York, 2003.

[3] Vannini M., Marchese P., Celli A., Lorenzetti C.: Green Chemistry 2015, 17, 4162. https://doi.org/10.1039/C5GC00991J

[4] Bozell J.J., Petersen G.R.: Green Chemistry 2010, 12, 539. https://doi.org/10.1039/B922014C

[5] Knoop R.J.I., Vogelzang W., Van Haveren J., Van Es D.S.: J. Polym. Sci. Part A: Polym. Chem. 2013, 51, 4191-4199. https://doi.org/ 10.1002/pola.26833

[6] Wilsens C.H.R.M.: "Exploring the application of 2,5-furandicarboxylic acid as a monomer in high performance polymers: Synthesis, characterization, and properties". PhD Diddertation, Technische Universiteit Eindhoven, Netherlands, 2015.

[7] Iwata T.: Journal of the German Chemical Society 2015, $54,3210$. https://doi.org/10.1002/anie.201410770

[8] Loos K., Zhang R., Pereira I. et al.: Frontiers in Chemistry 2020, 8, 1. https://doi.org/10.3389/fchem.2020.00585

[9] Zhang J., Liu Y., Qi Z. et al.: BioResources 2020, 15, 4502. https://doi.org/10.15376/biores.15.2

[10] Xie H., Wu L., Li B.G., Dubois P.: Polymer 2018, 155, 89. https://doi.org/10.1016/j.polymer.2018.09.033

[11] Poulopoulou N., Kantoutsis G., Bikiaris D.N. et al.: Polymers 2019, 11, 1. https://doi.org/10.3390/polym11060937

[12] Kasmi N., Wahbi M., Papadopoulos L. et al.: Polymer Degradation and Stability 2019, 160, 242. https://doi.org/10.1016/j.polymdegradstab.2019.01.004

[13] Chi D., Liu F., Na H. et al.: ACS Sustainable Chemistry and Engineering 2018, 6, 9893. https://doi.org/10.1021/acssuschemeng.8b01105

[14] Paszkiewicz S., Janowska I., Pawlikowska D. et al.: Express Polymer Letters 2018, 12, 530. https://doi.org/10.3144/expresspolymlett.2018.44

[15] Zubkiewicz A., Szymczyk A., Paszkiewicz S.: Polymer Engineering and Science 2021, 61, 1536. https://doi.org/10.1002/pen.25675

[16] Paszkiewicz S., Irska I., Zubkiewicz A. et al.: Polymers 2021, 13(3), 397. https://doi.org/10.3390/polym13030397

[17] Zhang J., Liang Q., Xie W. et al.: Polymers 2019, 11, 197. https://doi.org/10.3390/polym11020197

[18] Papageorgiou G.Z., Tsanaktsis V., Papageorgiou D.G. et al.: European Polymer Journal 2015, 67, 383. https://doi.org/10.1016/j.eurpolymj.2014.08.031

[19] Sanusi O.M., Papadopoulos L., Klonos P.A. et al.: Polymers 2020, 12, 1239. https://doi.org/10.3390/polym12061239

[20] Wang G., Jiang M., Zhang Q. et al.: Polymer Degradation and Stability 2018, 153, 272.

https://doi.org/10.1016/j.polymdegradstab.2018.05.010

[21] Guidotti G., Soccio M., García-Gutiérrez M.C. et al.: ACS Sustainable Chemistry and Engineering 2020, 8, 9558.

https://doi.org/10.1021/acssuschemeng.0c02840

[22] Wang G., Jiang M., Zhang Q. et al.: Polymer Degradation and Stability 2018, 153, 292.

https://doi.org/10.1016/j.polymdegradstab.2018.04.034

[23] Terzopoulou Z., Tsanaktsis V., Nerantzaki M. et al.: Polymer Degradation and Stability 2016, 132, 127. https://doi.org/10.1016/j.polymdegradstab.2016.03.006

[24] Jiang M., Liu Q., Zhang Q., Ye C., Zhou G.: Journal of Polymer Science Part A. Polymer Chemistry 2012, 50, 1026. https://doi.org/10.1002/pola.25859

[25] Paszkiewicz S., Irska I., Piesowicz E.: Materials 2020, 13, 2673. https://doi.org/10.3390/ma13122673

[26] Kwiatkowska M., Kowalczyk I., Kwiatkowski K. et al.: Polymer 2016, 99, 503.

https://doi.org/10.1016/j.polymer.2016.07.060

[27] Kowalczyk I., Kwiatkowska M., Rosłaniec Z.: Elastomery/Elastomers 2016, 20, 40.

[28] Novikov V.N., Rössler E.A.: Polymer 2013, 54, 69876991.

https://doi.org/10.1016/j.polymer.2013.11.002

[29] Fox T.G., Flory P.J.: Journal of Polymer Science 1954, 14, 315. https://doi.org/10.1002/pol.1954.120147514

[30] Hao T., Yu D., Ming Y. et al.: CrystEngComm 2020, 22, 1779. https://doi.org/10.1039/C9CE01606F

[31] Martin J.R., Johnson J.F., Cooper A.R.: Journal of Macromolecular Science Part C Polymer Reviews 2006, 8, 57. https://doi.org/10.1080/15321797208068169

[32] Gentekos D.T., Sifri R.J., Fors B.P.: Nat. Rev. Mater. 2019, 4, 761-774. https://doi.org/10.1038/s41578-019-0138-8

Received 13 IX 2021 